\title{
SPATIAL CONCENTRATION AS A PREMISE FOR BUILDING RELATIONS: AN APPLICATION IN POLISH ORGANIC FOOD CLUSTERS
}

\author{
Dominika Kuberska $^{1 凶}$, Eleanor Doyle ${ }^{2}$ \\ ${ }^{1}$ University of Warmia and Mazury in Olsztyn, Poland \\ ${ }^{2}$ University College Cork, Ireland
}

\begin{abstract}
Economic activity is embedded in the reality of a given region and its market structure. This regularity also materializes in agri-food markets. Location plays an important role in building competitive advantage because geographic proximity, resulting from location decisions of entities operating within an industry, is a significant condition for selected market activities. The accumulation of entities in the form of clusters may generate positive effects. Relations are established within and across geographic borders, and can result in the development of markets and their participants. The main purpose of this paper is to determine the premises for identifying clusters in the Polish organic food market which can provide a framework for building relations resulting in further development. The empirical investigation is based on 2016 data obtained from the Polish Agricultural and Food Quality Inspection and the Eurostat database, and employs descriptive statistics presented from various geographical perspectives (both national and regional). The concentrations of entities in the organic food market are estimated and assessed taking regional perspectives into consideration. Premises indicating the possibility for cluster development in the Polish organic food market were identified. Acknowledging such structural features should enable relations to be established that could translate into further development of the entities and of the entire market.
\end{abstract}

Keywords: organic food market, cluster, relations

\section{INTRODUCTION}

There are several reasons why the organic food market is an interesting target for analysis. One of them comes from the fact that it is a regulated market. Its regulation seeks to serve different purposes; there are various domain-specific reasons behind it that target production, processing, certification, consumption, trade and market, and media (Freyer et al., 2014). For example, as the demand for organic food is growing, so is the need to determine what 'organic' means (Nowacek and Nowacek, 2008). Consumer awareness of environmental issues started in the 1970s and so has the demand for environmentally-friendly products (Loureiro et al., 2001). Regulatory bodies want to protect consumers who have experienced many food-related crises and scandals over the last years (Jahn et al., 2005).

Organic certification is one of the clearest manifestations of regulation. It is meant as an assurance to consumers that the products labeled as organic are "grown, processed, and packaged according to rules" (Lohr, 1998). Also, when looking at the organic food market from another perspective, eco-labeling is meant as a way to cope with the complexity of values related to organic food systems (Læssøe et al., 2014). Many aspects of the system are condensed in identifiable symbols that are used among different actors. Regulation of

\footnotetext{
Dominika Kuberska, PhD, Department of Market Analysis and Marketing University of Warmia and Mazury in Olsztyn, Prawocheńskiego 19/100 St., 10-720 Olsztyn, Poland, e-mail: dominika.kuberska@uwm.edu.pl, https://orcid.org/0000-0001-7100-1017
} 
the organic food market also serves the producers. Without proper certification systems, information asymmetry on the market may deepen. It will then lead to consumers refusing to pay premium prices and thus some producers will be forced to leave the market (Nestorowicz, 2018). Nonetheless, certification systems "are susceptible to opportunistic behavior" (Jahn et al., 2005). In the European Union, the regulations apply to farming practices in agriculture and aquaculture, food processing, labeling, certification procedures and imports of organic products from outside the EU.

Recently recorded growth rates of the organic food market are remarkable. Hence, prospects for future growth remain promising. Its development is influenced by many factors, with demand growth as the main driving force, especially in western countries across Europe, North America, Australia and New Zealand (Marian et al., 2014; KRAV, 2014; Organic..., 2017; Soil Association, 2019). In developed countries, consumers are buying more organic food than their counterparts from other parts of the world. This is particularly true for Europe and North America (Baker, 2015). One of the reasons is that consumers associate organic food with health benefits (Hughner et al., 2007). Other perceived benefits include environmental friendliness and better taste than conventional food (Gottschalk and Leistner, 2013).

As demand for organic food is growing, so is organic agricultural land and the number of producers (IFOAM, 2010; 2019). However, demand growth surpasses supply growth (Willer et al., 2019) which results in increasing prices and should attract more businesses into the market. Effective efforts must be designed and executed to overcome this adversity. Some of them are related to the structure of the supply side of the market.

Before organic food reaches consumers, a growing array of operators assume their roles within the structure of the supply chain. Many linkages arise between them. In some circumstances, the networks take the form of clusters: geographically proximate groups of interconnected companies and associated institutions in a particular field, linked by commonalities and externalities (Porter, 2008). That clusters generate many advantages has been a finding across a range of research dealing with separate geographic levels. Specifically, benefits crucial to economic development have been identified at national (Rocha and Sternberg, 2005), regional (Porter, 2003) and local levels (Glaeser et al., 1992; Feser et al., 2008). Spatial concentration of linked entities is a key condition for cluster occurrence and, intuitively, that is the basis for positive agglomeration externalities that may emerge. For example, strong clusters have been resilient to the recent financial crisis as their share in total traded industry employment and wages increased between 2008 and 2014 (Ketels and Protsiv, 2016).

Cluster research has been conducted frequently in agriculture and the food industry in Poland (e.g. Figiel et al., 2014a; 2014b; Kuberska and Grzybowska-Brzezińska, 2017). However, the organic food market can be considered a distinct form combining both food and agricultural industries under a mix of policies suitable for public intervention and support. Such intervention is mainly aimed at granting financial support which, e.g. in the European Union, include incentives established under the Common Agricultural Policy (CAP). CAP instruments largely determine the income generated by organic farms (Gołaś, 2016). Occasionally - either through external intervention or by independent decisions of farm owners or others in their supply chains organic operators are motivated to establish formal as well as informal linkages between them. Within clusters, these relations may take different forms. Fundamentally, they can be divided into competition- and cooperation-based linkages. In some instances, a relation between two entities can transform into coopetition, i.e., simultaneous competition and cooperation. However, the outcome of these linkages importantly depends on the distance between market actors. Spatial concentration between operators in the organic food market must be taken into account when aiming to establish or support such beneficial relations. This is especially so in the organic food production and processing which are particularly tied to location, given the perishable nature of the produce. Clusters are the arena for establishing formal linkages under the auspices of cluster organizations. The European Cluster Observatory identifies six organic food cluster organizations in Europe in its database (European Cluster Observatory). However, given the data collection methodology, this number might not reflect the actual number of cluster organizations in the European organic food market.

Having the above in mind, the main purpose of this paper is to determine the premises for identifying clusters in the Polish organic food market which could provide a framework for building relations resulting in its further development. To achieve this, the paper was structured as follows: the next section deals with sources 
of materials and methods employed in the analysis. It is followed by a discussion of the results which begins by comparing Poland to other organic food markets in the European Union. Further results presented in the paper concern the location of various types of organic operators in Poland from different regional perspectives.

\section{MATERIAL AND METHODS}

Developing a cluster mapping methodology has been an academic concern for various reasons. It is so mainly because the proper identification and extraction of clusters is crucial to fully understand cluster dynamics and design appropriate cluster policies. Cluster mapping in the organic food market is facilitated by the fact that it is an example of a regulated market where operators undergo strict certification processes. As the market is subject to rigid controlling institutions which ensure consumer welfare and protection, its operators are easily identifiable and accounted for. Such circumstances facilitate cluster mapping at different levels of geographic aggregation.

This paper presents findings pertaining to cluster mapping, based on location, which enables the identification of specific elements of market structures between different types of entities. As the market has its own characteristics, it is also comprised of different types of actors. Therefore, the carefully collected data used for the purposes of this research was extracted from a database obtained from the Agricultural and Food Quality Inspection (IJHARS). The database includes a range of information covering the type, number, and location of organic operators in Poland. Some data on the organic food market was also obtained from the Eurostat database. The analysis is based on 2016 figures and employs descriptive statistics.

In terms of geographic scope of this analysis, calculations were performed at different geographic scales. The first level of analysis relates to national data across the EU-28. The purpose of this perspective was to compare the size of organic food markets between member states to provide an initial proxy for the size of organic food clusters considered at national level. To further analyze the Polish organic food market, two geographic perspectives were employed. First and foremost, the analysis was carried out at NUTS2 level, i.e. Polish voivodeships, followed by some further disaggregated calculations at NUTS3 level, i.e. Polish districts.

\section{RESULTS AND DISCUSSION}

The development of the Polish organic food market has been influenced by many factors. The Common Agricultural Policy has played a crucial role in this regard. Undeniably, the CAP has had a considerable impact on European agriculture as well as on its related and supporting industries (Moschitz and Stolze, 2007). The Polish organic food market has been growing as a part of the larger market within the confines of EU borders (Kułyk and Michałowska, 2016). The proximity of other member states' markets significantly affects the Polish system through a network of competitive and cooperative relations.

The strength of relations depends on the number, location, and concentration of entities that form them. This is why the initial stage of cluster mapping at any geographic level is performed through a careful consideration of the number of entities operating within the market. The number of organic operators registered in the EU varies across countries and implies differences in the potential for cluster development both within national borders and across the EU (Table 1).

As of $201620.3 \%$ of all the EU-28 operators were registered in Italy, followed by France (13.3\%), and Germany (11.6\%). Agricultural producers form the largest share of all operators. In absolute terms, the countries with the highest share of agricultural producers were Italy (21.7\%), Spain (12.2\%), and France (10.9\%). The main drivers of demand for organic produce offer some insight into patterns evident in Table 1. While some consumers perceive organic as a more natural, healthier and tastier alternative to conventional food with a smaller environmental impact (Aertsens et al., 2009; Technomic, 2017), this view is also challenged. And a more pessimistic position has also been expressed, i.e. that organic produce is overpriced, no different to conventional food, and represents a marketing trick of the food service provision sector to make customers over-pay (Guilabert and Wood, 2012).

For Europe and its sub-markets, a growth of $18 \%$ is expected by 2021 (comparative growth for the US is forecasted at $16.5 \%$, Frost and Sullivan, 2018). Demand is expected to outstrip supply with substantial market potential yet to be exploited. Hence, on balance, an optimistic view prevails and it is associated with the appearance of discerning customers in developed countries. The demand for organic produce will keep rising. Simultaneously, 
Kuberska, D., Doyle, E. (2019). Spatial concentration as a premise for building relations: an application in Polish organic food clusters. J. Agribus. Rural Dev., 3(53), 203-214. http://dx.doi.org/10.17306/J.JARD.2019.01118

Table 1. EU28 organic operators by selected categories in 2016

\begin{tabular}{|c|c|c|c|c|c|c|}
\hline \multirow{3}{*}{ Country } & \multicolumn{6}{|c|}{ Category } \\
\hline & \multicolumn{2}{|c|}{ all operators } & \multirow{2}{*}{$\begin{array}{l}\text { agricultural } \\
\text { producers }\end{array}$} & \multirow{2}{*}{ processors } & \multirow{2}{*}{ importers } & \multirow{2}{*}{ exporters } \\
\hline & (number) & $(\%)$ & & & & \\
\hline Italy & 72,154 & 20.30 & 64,227 & 16,578 & 363 & 518 \\
\hline France & 47,106 & 13.25 & 32,266 & 12,826 & 316 & - \\
\hline Germany & 41,296 & 11.62 & 27,636 & 14,494 & 1,605 & 787 \\
\hline Spain & 39,744 & 11.18 & 36,207 & 3,810 & 205 & 92 \\
\hline Austria & 26,625 & 7.49 & 24,213 & 1,683 & 57 & 10 \\
\hline Poland & 23,375 & 6.58 & 22,435 & 705 & 120 & 180 \\
\hline Greece & 21,877 & 6.16 & 20,192 & 1,463 & 15 & 70 \\
\hline Romania & 10,562 & 2.97 & 10,083 & 150 & 5 & 5 \\
\hline Bulgaria & 7,262 & 2.04 & 6,964 & 175 & 13 & 9 \\
\hline Sweden & 7,058 & 1.99 & 5,741 & 1,144 & 165 & 10 \\
\hline United Kingdom & 6,514 & 1.83 & 3,402 & 2,969 & 135 & 0 \\
\hline Finland & 5,419 & 1.52 & 4,493 & 672 & 78 & 11 \\
\hline Portugal & 5,051 & 1.42 & 4,246 & 639 & 15 & 1 \\
\hline Czech Republic & 4,903 & 1.38 & 4,271 & 616 & 190 & 96 \\
\hline Denmark & 4,470 & 1.26 & 3,306 & 972 & 74 & 89 \\
\hline Latvia & 4,365 & 1.23 & 4,145 & 48 & 9 & 1 \\
\hline Netherlands & 4,033 & 1.13 & 1,557 & 990 & 364 & 81 \\
\hline Hungary & 3,968 & 1.12 & 3,414 & 442 & 34 & 0 \\
\hline Slovenia & 3,842 & 1.08 & 3,513 & 310 & 14 & 0 \\
\hline Croatia & 3,673 & 1.03 & 3,546 & 312 & 8 & 0 \\
\hline Belgium & 3,572 & 1.00 & 1,946 & 1,116 & 183 & 84 \\
\hline Lithuania & 2,743 & 0.77 & 2,539 & 65 & 11 & 2 \\
\hline Ireland & 2,099 & 0.59 & 1,765 & 274 & 23 & 2 \\
\hline Estonia & 1,868 & 0.53 & 1,753 & 135 & 26 & 0 \\
\hline Cyprus & 1,332 & 0.37 & 1,174 & 57 & 4 & 4 \\
\hline Slovakia & 598 & 0.17 & 431 & 36 & 13 & 2 \\
\hline Luxembourg & 179 & 0.05 & 93 & 82 & 4 & 0 \\
\hline Malta & 37 & 0.01 & 14 & 7 & 13 & 0 \\
\hline EU28 & 355,424 & 100 & 295,618 & 62,640 & 4,066 & $2,054 *$ \\
\hline
\end{tabular}

Note: The sums of producers, processors, importers and exporters do not sum to all operators as some types of operators are not included in the above figures while others assume more than one role in the market.

- not available

*Excluding France.

Source: own elaboration based on Eurostat database. 
a call for greater transparency in steps of the food chain will become more prominent due to health, taste, environmental sustainability, and social responsibility purposes.

On the supply side, organic farming has not developed equally across Europe. Moschitz and Stolze (2007) highlight that Austria and Denmark exhibit the most developed organic sectors whereas the UK and Italy lag behind. While having a developed organic sector, Germany is also the largest organic market in Europe. Although evolving under the shared background of the Common Agricultural Policy (CAP), and albeit in the context of generally growing demand, the countries have uneven experiences with different shares of organic farming in the overall agricultural sector (Michelsen et al., 2001).

As shown in Table 1, other entities in the organic food market value chain are processors, exporters and importers. Of all the EU processors, $26.5 \%$ were registered in Italy, with $23.1 \%$ in Germany and $20.5 \%$ in France, i.e. $70 \%$ of all the EU processors are located within these three countries. Similar data on the share of processors relative to total agricultural producers per country, reveals interesting differences: the respective shares are $87 \%$ in the UK, $64 \%$ in the Netherlands and $57 \%$ in Belgium. The average figure across the EU-28 was $24 \%$; other countries above that level included Germany (52\%), France (40\%) and Denmark (29\%), whereas the percentage for Italy was closer to average (26\%). These figures are important indicators of the extent to which local produce is processed locally and whether value is added locally. For Poland, that ratio is $3 \%$, indicating substantial potential for development within the Polish organic food market if the local capabilities can diversify to add value to agricultural output. When it comes to trade with non-EU countries, over 4,000 importers and over 2,000 exporters were registered in the EU.

Therefore, within the international EU context, the Polish organic food market faces competition from larger western markets. Poland is home to $6.6 \%$ of all the EU operators and $7.6 \%$ of agricultural producers. The Polish organic food market in 2016 was comprised of 705 processors, 120 importers, and 180 exporters.

Cluster mapping within the confines of a country is performed by examining the regional distribution of economic operators. Table 2 presents location data

Table 2. Polish NUTS2 regions by organic agricultural producers in 2016

\begin{tabular}{|c|c|c|c|c|}
\hline \multirow{3}{*}{ Region } & \multicolumn{4}{|c|}{ Category } \\
\hline & \multicolumn{2}{|c|}{ all organic agricultural producers } & \multirow{2}{*}{$\begin{array}{c}\text { certified organic agricultural } \\
\text { producers }(\%)\end{array}$} & \multirow{2}{*}{$\begin{array}{c}\text { organic agricultural producers } \\
\text { in conversion }(\%)\end{array}$} \\
\hline & (number) & $(\%)$ & & \\
\hline Warmińsko-Mazurskie & 4,142 & 18.5 & 18.3 & 19.1 \\
\hline Podlaskie & 3,437 & 15.3 & 15.4 & 14.9 \\
\hline Zachodniopomorskie & 2,573 & 11.5 & 12.8 & 6.5 \\
\hline Mazowieckie & 2,426 & 10.8 & 9.6 & 15.5 \\
\hline Lubelskie & 1,980 & 8.8 & 8.4 & 10.4 \\
\hline Podkarpackie & 1,252 & 5.6 & 5.8 & 4.9 \\
\hline Lubuskie & 1,148 & 5.1 & 5.2 & 4.8 \\
\hline Małopolskie & 1,093 & 4.9 & 5.3 & 3.1 \\
\hline Wielkopolskie & 843 & 3.8 & 3.3 & 5.3 \\
\hline Świętokrzyskie & 834 & 3.7 & 4.0 & 2.7 \\
\hline Dolnośląskie & 813 & 3.6 & 3.7 & 3.3 \\
\hline Pomorskie & 679 & 3.0 & 3.2 & 2.3 \\
\hline Łódzkie & 497 & 2.2 & 2.1 & 2.6 \\
\hline Kujawsko-Pomorskie & 470 & 2.1 & 1.7 & 3.7 \\
\hline Śląskie & 180 & 0.8 & 0.9 & 0.6 \\
\hline Opolskie & 68 & 0.3 & 0.3 & 0.2 \\
\hline
\end{tabular}

Source: own elaboration based on IJHARS, 2018a; 2018 b. 
focusing specifically on agricultural producers across sixteen Polish regions (voivodeships).

The main type of market activity is agricultural production: it should be thus recognized as the core or basic activity of the cluster. In 2016 three regions (voivodeships, i.e., the Polish equivalent of NUTS2 regions) were home to the largest shares of organic agricultural producers. These were Warmińsko-Mazurskie (18.5\%), Podlaskie (15.3\%), and Zachodniopomorskie (11.5\%) voivodeships. Thus, organic agricultural production is concentrated in three regions, two of which are located in north-east Poland and border each other. The third region is located in north-west Poland. The spatial distribution of producers is consistent to a certain extent with Gabriel et al.'s (2009) explanation of the varied reasons underlying the organic farming pattern observed in England, namely: focus on mixed livestock, land quality differences, length of the growing season and distance from urban centers.

The disentangling of relations within a cluster, after indicating the core activity of the cluster, consists in isolating other market stakeholders, specifically those involved in its supply chain. There are different types of operators in the organic food market in addition to agricultural producers. Processors are another important group of operators (Fig. 1) that add value to agricultural produce (beyond the commodity value). The Mazowieckie voivodship hosts $24.7 \%$ of processors, followed by the Wielkopolskie voivodship with $11.3 \%$, the Małopolskie voivodeship (9.4\%) and the Lubelskie voivodeship (9.2\%). None of these locations, however, coincide with the three largest concentrations of agricultural producers.

Such a discrepancy or lack of alignment characterizes the industry profile of Polish organic food regions. It is, however, not out of line with the situation in England and Wales (Ilbery and Maye, 2011). Notwithstanding this measure, the voivodeships with the largest shares of agricultural producers border those with the largest shares of processors. Both WarmińskoMazurskie and Podlaskie voivodeships (ranked $1^{\text {st }}$ and $2^{\text {nd }}$ in share of producers, respectively) are located next to the region with the highest share of processors i.e. the Mazowieckie voivodeship $\left(1^{\text {st }}\right)$. In addition, the Zachodniopomorskie voivodeship $\left(3^{\text {rd }}\right)$ is a neighboring region of the Wielkopolskie voivodeship $\left(2^{\text {nd }}\right)$. These indicators may be considered favorable for targeting the relations established between these two

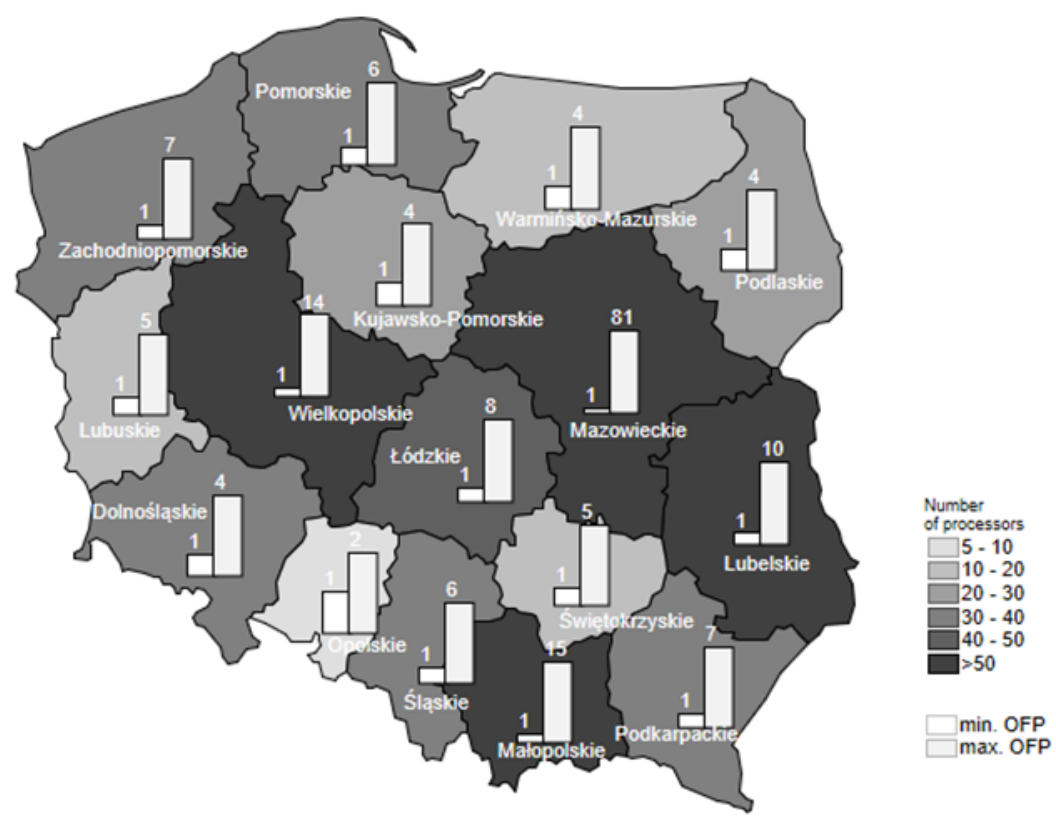

Fig. 1. Polish NUTS2 regions by number of organic processors in 2016 Source: own elaboration based on IJHARS, 2018c. 
groups of operators. Overall, while being the region with the highest share of processors, the Mazowieckie voivodeship is also ranked $4^{\text {th }}$ in the number of agricultural producers $(10.8 \%)$. Also, the Lubelskie voivodeship is a region with relatively large shares in both categories $(8.8 \%$ of agricultural producers and $9.2 \%$ of processors; $5^{\text {th }}$ and $4^{\text {th }}$, respectively).

The ratio between the number of agricultural producers and processors varies significantly across NUTS2 regions. In 2016, the Warmińsko-Mazurskie voivodeship ranked $1^{\text {st }}$ with 202 agricultural producers per processor, followed by the Podlaskie voivodeship with 109. At the other end of the spectrum, there are voivodeships such as Łódzkie, Wielkopolskie, and Śląskie with a ratio of 9,7 , and 5 respectively. These measures point to potential for increasing the producer-to-processor ratios, and developing further those locations where the ratios are already the highest.

It is possible to focus the analysis even more sharply, drilling down from NUTS2-level regions looking into the distribution and concentration of organic processors at NUTS3 level, which offers a more in-depth location analysis. Again, wide distribution is observed of processors across districts (Polish equivalent of NUTS3 regions). The dispersion is confirmed when measuring the share of districts with organic processors across all districts within each voivodeship. For example, in voivodeships such as Pomorskie, Małopolskie, and Zachodniopomorskie, more than $80 \%$ of districts are home to processing businesses. In Warmińsko-Mazurskie and Opolskie voivodeships, the shares are lower (47.6\% and $33.3 \%$, respectively). This initial measure is not a complete description of how the processors are concentrated. Combining this information with numbers of processors in each district (Fig. 2) is a way to identify the respective shares of processors in each district.

In several cases, one district, or neighboring districts, are home to a relatively large number of processors. This observation provides grounds for mapping potentially strong clusters because the proximity between processors - especially when backed by proximity of other operators of the organic food market - may support strengthening the relations between them, resulting in further development of the market.

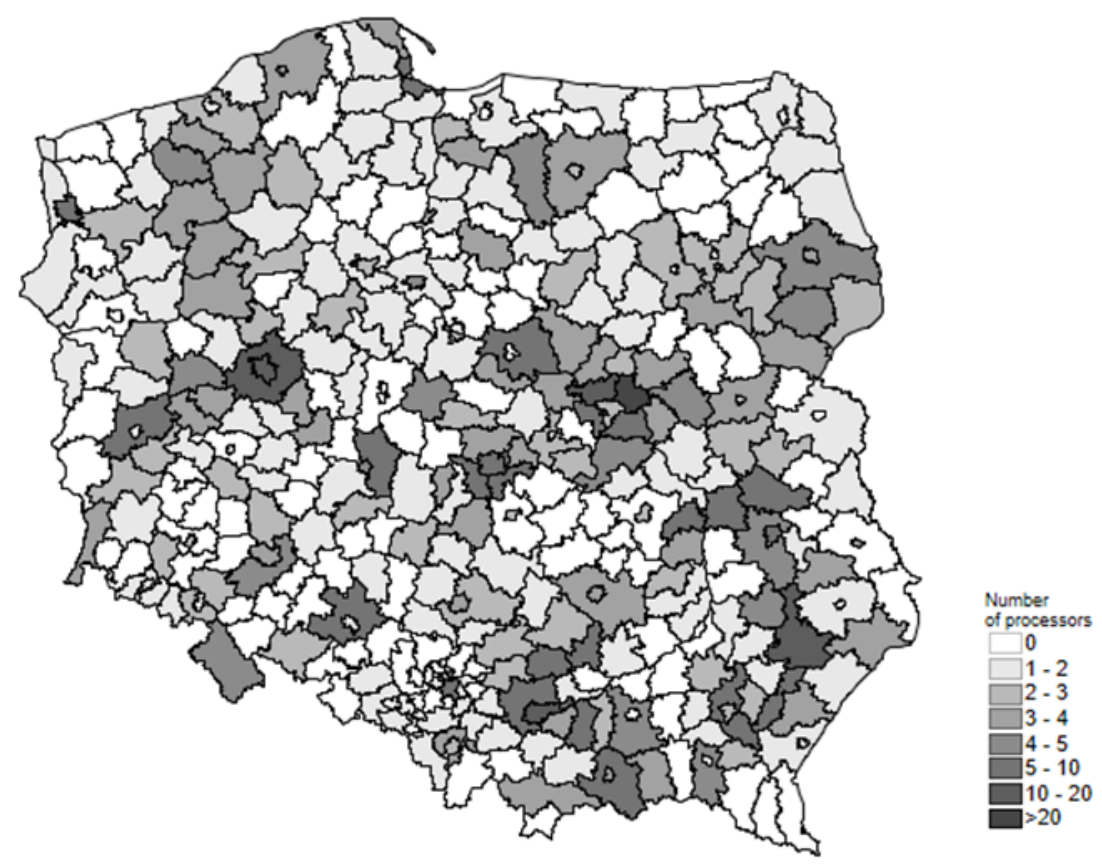

Fig. 2. Organic processors by NUTS3 regions in 2016 Source: own elaboration based on IJHARS, 2018c. 
Interestingly, Ilbery and Maye (2011) point to a lack of 'organic' infrastructure in England (south-east) with farmers admitting to a preference to remain independent and competitive, and little evidence of any neighborhood or spill-over effects of shared benefits. In contrast, Wales (south-west) revealed a longer embeddedness of organic producers who took advantage of supply and marketing cooperatives to address limited local demand for organic produce. In the Danish context, Risgaard et al. (2007) identified conversion to organic farming as being due to a range of socio-cultural reasons including the presence of 'champion' organic farmers, ambassadors from advisory organizations, local farmer organizations, formal cooperative marketing arrangements, as well as informal networking, discussion groups and knowledge transfer. While spatial clustering was evident in Denmark, it was not the case in England; the sector remained quite small compared to other sectors of agriculture, even though it is well developed in relation to other locations.

Furthermore, some of the entities within the Polish organic food market simultaneously perform more than one type of activity within the supply chain. In 2016, 238 agricultural producers $(1.1 \%$ of all agricultural producers) conducted other types of operations (including processing) whereas 476 processors $(67.5 \%$ of all processors) were engaged in other operations (including agricultural production). Overall, entities in the market's upstream industry (agricultural production) are less likely to be engaged in other types of supply chain activity while the opposite is the case for entities in downstream industry (processing) i.e. they are

Table 3. Other organic operators in the Polish organic food market by NUTS2 regions in 2016 (\%)

\begin{tabular}{|c|c|c|c|c|c|c|c|}
\hline \multirow[b]{2}{*}{ Region } & \multicolumn{7}{|c|}{ Category } \\
\hline & $\begin{array}{l}\text { aquaculture } \\
\text { production } \\
(5)\end{array}$ & $\begin{array}{c}\text { beekeeping } \\
\text { (32) }\end{array}$ & $\begin{array}{c}\text { harvesting } \\
\text { from natural } \\
\text { state } \\
(37)\end{array}$ & $\begin{array}{l}\text { import } \\
(120)\end{array}$ & $\begin{array}{l}\text { export } \\
(180)\end{array}$ & $\begin{array}{c}\text { traders } \\
\text { (intra-EU) } \\
(720)\end{array}$ & $\begin{array}{c}\text { seed material } \\
(143)\end{array}$ \\
\hline Dolnośląskie (79) & - & 9.4 & 2.7 & 6.7 & 5.0 & 6.3 & 9.1 \\
\hline Kujawsko-Pomorskie (30) & - & - & - & 1.7 & 1.7 & 2.2 & 6.3 \\
\hline Lubelskie (115) & - & - & 29.7 & 6.7 & 8.3 & 9.3 & 9.8 \\
\hline Lubuskie (23) & 20 & 3.1 & - & - & 0.6 & 1.7 & 5.6 \\
\hline Łódzkie (81) & 40 & 3.1 & - & 10 & 9.4 & 6.1 & 3.5 \\
\hline Małopolskie (86) & - & 6.3 & 5.4 & 5 & 7.2 & 7.9 & 4.2 \\
\hline Mazowieckie (301) & 20 & 12.5 & 5.4 & 27.5 & 26.7 & 28.1 & 7.7 \\
\hline Opolskie (12) & - & - & - & 0.8 & 1.1 & 1 & 1.4 \\
\hline Podkarpackie (73) & - & 28.1 & 10.8 & 5.8 & 8.3 & 4.9 & 2.1 \\
\hline Podlaskie (55) & - & 9.4 & 8.1 & 5.8 & 4.4 & 3.9 & 4.2 \\
\hline Pomorskie (67) & - & 6.3 & 13.5 & 8.3 & 3.3 & 4.6 & 7.7 \\
\hline Śląskie (52) & - & - & - & 4.2 & 5 & 5.3 & - \\
\hline Świętokrzyskie (27) & - & 3.1 & - & 3.3 & 3.3 & 2.2 & - \\
\hline Warmińsko-Mazurskie (30) & - & 3.1 & - & - & 1.1 & 2.1 & 8.4 \\
\hline Wielkopolskie (135) & 20 & 6.3 & 5.4 & 11.7 & 11.7 & 11 & 11.2 \\
\hline Zachodniopomorskie (71) & - & 9.4 & 18.9 & 2.5 & 2.8 & 3.6 & 18.9 \\
\hline
\end{tabular}

- Does not occur.

Source: own elaboration based on IJHARS, 2018d. 
more likely to be engaged in other elements of the supply chain.

About $4.2 \%$ of all operators perform activities other than agricultural production and processing, whereas approximately $1.34 \%$ of all operators carry out businesses that involve neither of these activities (these additional activities are set out in Table 3). Moreover, only $0.2 \%$ of all organic operators simultaneously perform agricultural production and processing. As only a relatively small portion of entities diversify their activities, the proximity of other operators would appear essential for establishing beneficial relations within potential clusters. Given the 'heterogeneous and multidimensional' characteristics of the organic sector identified in e.g. Ilbery and Maye (2011), the various and specific local conditions do not necessarily translate to other locations. Further consideration of such microrelationships need to be considered when deciding on the nature and extent of any clustering and cooperation between producers, processors or both groups. This may take the form of qualitative research into the experience of individual organic producers and processors.

Both raw materials and final products need to be relocated as they move through the supply chain. Hence, traders (intra-EU exporters and importers), exporters, and importers perform important functions for the organic food market. These types of operations should be considered as entities supporting the cluster's core activity of production. In all three categories, the Mazowieckie voivodeship is the leader in terms of the share of intra-EU traders, importers, and exporters. Interestingly, relatively low scores were exhibited by the Warmińsko-Mazurskie voivodeship (2.1\% of intra-EU traders in Poland, $1.1 \%$ of exporters, and $0 \%$ of importers). In absolute terms, 5 operators are active in aquaculture production. Beekeeping (32 entities) is highly concentrated in the Podkarpackie voivodeship (28.1\%). In turn, the Lubelskie voivodeship (29.7\%) specializes in harvesting produce from its raw, or natural, state. Finally, seed producers are dispersed among 14 out of 16 regions, with just over $30 \%$ of operators registered in the Zachodniopomorskie and Wielkopolskie voivodeships.

\section{CONCLUSIONS}

In the Polish organic food market, the operators are unevenly distributed across the national territory. As part of a development approach, it is worth identifying the potential for clusters as geographic concentrations of companies and associated institutions. This will allow to consider the patterns within such a geography and find out how they might be better supported to translate into economic impacts.

Organic agricultural production, organic processing as well as other types of activities are concentrated in certain regions. Warmińsko-Mazurskie, Podlaskie, and Zachodniopomorskie voivodeships lead the way with the highest shares of agricultural producers. At the same time, Mazowieckie, Wielkopolskie, Małopolskie, and Lubelskie voivodeships are the regions demonstrating the largest shares of organic processors. Interestingly, these voivodeships also specialize in conventional food processing. These findings are therefore an evidence of their organic sub-specialization. Moreover, the top three voivodeships are home to large metropolitan areas (Warsaw, Poznań, Krakow). They exhibit a larger share of population with a tertiary education and higher incomes than in other areas. These are also the characteristics of Polish organic food buyers (Żakowska-Biemans, 2003) which may explain why organic food processors are located close to organic food consumers.

Organic agricultural production and organic food processing are heavily interlinked and, therefore, the measures of regional concentration point to where (in geographic terms) cluster support might best be targeted to enhance the complementarity between cultivation and processing. One set of targeted clustering support would appear to be sensible given the predicted expansion of local Polish demand for organic produce. Hence, supporting organic producers and organic processors to better serve local markets could offer growth potential and locally-focused marketing support (Guthman, 2004). Given the regional specialization of organic agricultural production and organic food processing in Poland and the proximity of regions that host organic food clusters of both types of organic operators, it is advisable to support clustering initiatives in the voivodeships with the largest number of organic agricultural producers and organic food processors.

Spatial concentration is also observed in other industries related to and supporting organic food. In terms of potential for developing markets, both local operators and those responsible for international trade can be considered when focusing on developing the domestic and international markets, respectively. It is important to note that local economic benefits from organic 
conversion are not assured and, in the case of England, little difference was observed in the impact of conventional versus organic farming on the rural economy (Lobley et al., 2005).

Given the measures assembled here, locational concentration is an important premise in identifying clusters in the Polish organic food market. They are fundamental for building relations resulting in its further development. The need for strong relations between the discrete parts of the organic food supply chain stems from the fact that very few operators diversify their operations. That is, only a small portion of operators are engaged in more than one type of activity. Therefore, the flow of raw materials and final products depends on the right management of the supply chain.

As the number of organic operators increases, the spatial concentration in the market covered by this analysis will also undergo transformation. Further regional concentrations, especially in processing activities, are vital for the beneficial development of the market. Both operators and institutions should be aware of potential benefits arising from proximity and should make efforts to establish close relations with other actors. However, it remains open whether building linkages should be backed by public intervention. Up to now, the results of actions taken under the auspices of cluster policies have been mixed.

Analyzing regional specialization is a tricky task as the results depend on both the methodology employed and data. Therefore, the main limitation of this paper is the fact that clusters in the Polish organic food market were identified using data on the number of organic food operators rather than employment or output. With this in mind, further study on the location of organic food clusters across Polish regions is necessary. It would deepen the understanding of where potential relationships on the organic food market can be established which would benefit both the supply and the demand side of the market. Moreover, further microeconomic and qualitative research is needed to provide critical understanding of the "supposedly localized nature of organic food networks" (Clarke et al., 2008).

\section{SOURCE OF FINANCING}

This publication was written as a result of Dominika Kuberska's internship in Harvard University, co-financed by the European Union under the European Social Fund
("Knowledge Education Development" Operational Program), carried out in the Development Program project at the University of Warmia and Mazury in Olsztyn (POWR.03.05. 00-00-Z310/17).

\section{REFERENCES}

Aertsens, J., Verbeke, W., Mondelaers, K., van Huylenbroeck, G. (2009). Personal determinants of organic food consumption: a review. Brit. Food J., 111(10), 1140-1167.

Baker, B. (2015). A comparison of European and North American organic agriculture research policies. Proceedings of the Organic Agriculture Research Symposium, LaCrosse. Retrieved from: http://eorganic.info/sites/eorganic.info/ files/u27/02-Baker-EU\&NA_Comparison-Final.pdf.

Clarke, N., Cloke, P., Barnett, C., Malpass, A. (2008). The spaces and ethics of organic food. J. Rural Stud., 24(3), 219-30.

European Cluster Observatory database (n.d.). Retrieved from: http://www.clusterobservatory.eu/index.html\#!vie $\mathrm{w}=$ sectors $;$ mode $=$ one; sort $=$ name uid $=$ Organic $\% 20$ Food.

Eurostat database (2019). Retrieved from: http://appsso. eurostat.ec.europa.eu/nui/show.do?dataset=org_coptyp \&lang=en.

Feser, E., Renski, H., Goldstein, H. (2008). Clusters and economic development outcomes: an analysis of the link between clustering and industry growth. Econ. Dev. Quart., 22(4), 324-344.

Figiel, S., Kuberska, D., Kufel, J. (2014a). Agri-food clusters in Poland. Warsaw: Institute of Agricultural and Food Economics - National Research Institute.

Figiel, S., Kuberska, D., Kufel, J. (2014b). An analysis of conditions and the state of development of the agri-food clusters in Poland. Warsaw: Institute of Agricultural and Food Economics - National Research Institute.

Freyer, B., Bingen, J., Paxton, R. (2014). Can multicriteria assessment tools help build trust into organic products? Ecol. Soc., 19(4), 5-17.

Frost \& Sullivan (2018). Global animal feed phytogenics market, Forecast to 2021. Retrieved from: https://store.frost. com/global-animal-feed-phytogenics-market-forecastto-2021.html.

Gabriel, D., Carver, S., Durham, H., Kunin, W., Palmer, R., Sait, S., Stagl, S., Benton, T. (2009). The spatial aggregation of organic farming in England and its underlying environmental correlates. J. Appl. Ecol., 46(2), 323-333.

Glaeser, E., Kallal, H., Scheinkman, J., Shleifer, A. (1992). Growth in cities. J. Polit. Econ., 100(6), 1126-1152.

Gołaś, Z. (2016). Development of organic farming in Poland. J. Agribus. Rural Dev., 42(4), 533-543. 
Gottschalk, I., Leistner, T. (2013). Consumer reactions to the availability of organic food in discount supermarkets. Int. J. Cons. Stud., 37(2), 136-142.

Guilabert, M., Wood, A. (2012). USDA certification of food as organic: an investigation of consumer beliefs about the health benefits of organic food. J. Food Prod. Market., $18(5), 353-368$.

Guthman, J. (2004). The trouble with 'organic lite' in California: a rejoinder to the "conventionalisation" debate. Soc. Rural., 44(3), 301-316.

Hughner, R., McDonagh, P., Prothero, A., Shultz, II, C., Stanton, J. (2007). Who are organic food consumers? A compilation and review of why people purchase organic food J. Cons. Beh., 6(2-3), 94-110.

IFOAM (2010). 2009 annual report. Retrieved from: https:// www.ifoam.bio/en/our-library/annual-reports

IFOAM (2019). 2018 annual report. Retrieved from: https:// www.ifoam.bio/en/our-library/annual-reports

IJHARS (2018a). Wykaz ekologicznych producentów rolnych [List of organic agricultural producers]. Warszawa: Inspekcja Jakości Handlowej Artykułów Rolno-Spożywczych [in Polish].

IJHARS (2018b). Wykaz ekologicznych producentów rolnych (w konwersji) [List or organic agricultural producers (in conversion)]. Warszawa: Inspekcja Jakości Handlowej Artykułów Rolno-Spożywczych [in Polish].

IJHARS (2018c). Wykaz przetwórni ekologicznych [List of organic processors]. Warszawa: Inspekcja Jakości Handlowej Artykułów Rolno-Spożywczych [in Polish].

IJHARS (2018d). Wykaz pozostałych producentów ekologicznych [List of other organic operators]. Warszawa: Inspekcja Jakości Handlowej Artykułów Rolno-Spożywczych [in Polish].

Ilbery, B., Maye, D. (2011). Clustering and the spatial distribution of organic farming in England and Wales. Area, 43(1), 31-41.

Jahn, G., Schramm, M., Spiller, A. (2005). The reliability of certification: quality labels as a consumer policy tool. J. Cons. Pol., 28(1), 53-73.

Ketels, Ch., Protsiv, S. (2016). European cluster panorama 2016. Stockholm: Center for Strategy and Competitiveness.

KRAV (2014). Market report 2014. Retrieved from: http:// arkiv.krav.se/mrapport/krav-market-report-eng.pdf

Kuberska, D., Grzybowska-Brzezińska, M. (2017). A retrospective approach to cluster development in the context of the marketing chain in the Polish organic food market. J. Agribus. Rural Dev., 45(3), 591-599.

Kułyk, P., Michałowska, M. (2016). Stan rozwoju rolnictwa ekologicznego w Polsce w latach 2004-2014 [The Status of Development of Organic Farming in Poland in the years 2004-2014]. Zesz. Nauk. SGGW Warsz. Ekon. Org. Gosp. Żywn., 113, 17-32 [in Polish].

Læssøe, J., Kruse Ljungdahl, A., Alrøe, H., Noe, E., Christensen, T., Dubgaard A., Bøye Olsen, S., Kærgård, N., Kastberg, P. (2014). Three perspectives on motivation and multicriteria assessment of organic food systems. Ecol. Soc., 19(3), 7.

Lobley, M., Reed, M., Butler, A., Courtney, P., Warren, M. (2005). The impact of organic farming on the rural economy in England. Exeter: Centre for Rural Research, University of Exeter.

Lohr, L. (1998). Implications of organic certification for market structure and trade. American J. Agric. Econ., 80(5), $1125-1129$.

Loureiro, M., McCluskey, J., Mittelhammer, R. (2001). Assessing consumer preferences for organic, eco-labeled, and regular apples. J. Agric. Res. Econ., 26(2), 404-416.

Marian, L., Chrysochou, P., Krystallis, A., Thøgersen, J. (2014). The role of price as a product attribute in the organic food context: an exploration based on actual purchase data. Food Qual. Pref., 37, 52-60.

Michelsen, J., Lynggaard, K., Padel, S., Foster, C. (2001). Organic farming development and agricultural institutions in Europe: a study of six countries. Stuttgart-Hohenheim: Universität Hohenheim. Retrieved from: http://orgprints. org/8488/1/Organic_Farming_in_Europe_Volume09_Organic_Farming_Development_and_Agricultural_Institutions_in_Europe_A_Study_of_Six_Countries.pdf

Moschitz, H., Stolze, M. (2007). Policy networks of organic farming in Europe. Stuttgart-Hohenheim: Universität Hohenheim. Retrieved from: http://orgprints.org/4859/1/Organic_farming_in_Europe_Volume12_Policy_networks_ of_organic_farming_in_Europe.pdf

Nestorowicz R. (2018). Asymetria wiedzy a rozwój rynku żywności ekologicznej w Polsce [Knowledge asymmetry and development of the organic food market in Poland]. Handel Wewn., 376(5), 212-224 [in Polish].

Nowacek, D., Nowacek, R. (2008). The organic foods system: its discursive achievements and prospects. Coll. Eng., 70(4), 403-420.

Organic Trade Association (2017). Organic industry survey. Retrieved from: http://www.italianmade.com/wp-content/ uploads/2017/10/OTA_2017-Organic-Industry-Survey_ Exec-Summary-for-ITA-1.pdf

Porter, M. (2003). The economic performance of regions. Regional Studies, 37(6\&7), 549-578.

Porter, M. (2008). On competition, updated and expanded edition. Boston: Harvard Business School Publishing.

Risgaard, M., Frederiksen, P., Kaltoft, P. (2007). Socio-cultural processes behind the differential distribution of organic 
Kuberska, D., Doyle, E. (2019). Spatial concentration as a premise for building relations: an application in Polish organic food clusters. J. Agribus. Rural Dev., 3(53), 203-214. http://dx.doi.org/10.17306/J.JARD.2019.01118

farming in Denmark: a case study. Agric. Human Val., 24(4), 445-459.

Rocha, H., Sternberg, R. (2005). Entrepreneurship: the role of clusters theoretical perspectives and empirical evidence from Germany. Small Bus. Econ., 24(3), 267-292.

Soil Association (2019). Organic market 2019. Retrieved from: https://www.soilassociation.org/media/18224/omrreport-2019-interactive.pdf

Technomic (2017). Natural \& organic. Multi client study. Retrieved from: https://www.technomic.com/available-studies/multi-client-studies/natural-organic
Willer, H., Schaack, D., Lernoud, J. (2019). Organic farming and market development in Europe and the European Union. In H. Willer, J. Lernoud (Eds.), The world of organic agriculture. Statistics and emerging trends 2019 (pp. 217-247). Retrieved from: https://www.organic-world. net/yearbook/yearbook-2019/pdf.html

Żakowska-Biemans, S. (2003). Socjoekonomiczny profil konsumentów żywności ekologicznej [Socio-economic profile of organic food consumers]. Rocz. Nauk. SERiA, 5(3), 223-227 [in Polish]. 